\title{
RELATIONSHIP BETWEEN SOCIAL INTERACTION ABILITY AND WRITING SHORT STORY ABILITY
}

\author{
Anggun Citra Dini Dwi Puspitasari* \\ Universitas Indraprasta PGRI \\ Zetty Karyati \\ Universitas Indraprasta PGRI \\ Retna Ningsih \\ Universitas Indraprasta PGRI \\ Jn. Nangka no58 C Tanjung Barat Jagakarsa Jakarta Selatan \\ e-mail:anggun.citra.dini@gmail.com
}

\begin{abstract}
Writing is one of the skills that is difficult to master because in writing, a person must exert all his abilities. So even in writing short story, often a writer has difficulty in getting ideas, themes, or topics to be writing. Ideas, themes, or topics will be easily obtained if the writer has extensive experience, insight, and knowledge. Extensive experience, insight, and knowledge can be obtained from social interaction. Based on this fact, the researchers suspect the relationship between social interaction ability with writing short story ability. Researchers assume if the higher of students ability will be. Therefore, researchers conducted research to find out the relationship between social interaction ability to writing short story ability. The method used in this research is descriptive qualitative. From this research it is expected to know whether there is a relationship between social interaction ability with writing short story ability. After doing research, the results show that there is a relationship between social interaction ability with writing short story ability.

Key words: Ability, Social Interaction, and Writing Short Story.
\end{abstract}

Article History: Received: 22/09/2019; Revised: 21/10/2019; Accepted: 20/11/2019; Published:31/12/2019

How to Cite (MLA 7th): Puspitasari, A.C.D.D dan Karyati, Zetty "Relationship Between Social Interaction Ability and Writing Short Story Ability." Hortatori Jurnal Pendidikan Bahasa dan Sastra Indonesia 03.02 (2019): 100-103. Print/Online. Copyrights Holder: Puspitasari, A.C.D.D dan Karyati, Zetty. First Publication: Hortatori Jurnal Pendidikan Bahasa dan Sastra Indonesia (2019).

This work is licensed under a Creative Commons Attribution-ShareAlike 4.0 International License.

\section{Pendahuluan}

Menulis merupakan keterampilan yang paling sulit dikuasai dibanding dengan aspek keterampilan bahasa yang lainnya. Sebagaimana yang diutarakan oleh Sakura Ridwan (2011: 83), kemampuan menulis merupakan kemampuan yang kompleks, sebab menulis mengharuskan seseorang mengerahkan segenap kemampuannya yang berupa penguatan aspek-aspek kebahasaan, isi tulisan, teknik penulisan, dan juga tentang apa yang akan ditulis serta bagaimana menyampaikannya dalam bahasa tulis.

Berdasarkan pengalaman peneliti saat mengajar di MAN 13 Jakarta, peneliti menemukan berbagai permasalahan yang kurang menyenangkan berkaitan dengan kemampuan menulis cerpen siswa, yaitu dengan ditemukannya beberapa siswa yang memiliki kemampuan menulis cerpen yang rendah, dengan nilai di bawah 70 bahkan ada yang mendapat nilai 50. Ketika peneliti menanyakan pendapat siswa tentang kegiatan menulis cerpen, mereka berpendapat dan menganggap bahwa kegiatan menulis cerpen sebagai kegiatan yang menyulitkan, membosankan, menguras waktu dan pikiran, menuntut perhatian 
lebih, dan harus dilakukan dengan sungguh-sungguh. Di sini terlihat bahwa minat siswa dalam menulis cerpen sangatlah kurang.

Peneliti juga menanyakan kepada siswa tentang kesulitan-kesulitan apa saja yang mereka hadapi ketika menulis cerpen, sebagian besar siswa menjawab bahwa mereka kesulitan untuk mendapatkan ide, tema, atau topik yang akan ditulisnya. Ide, tema, atau topik akan mudah didapatkan siswa apabila mereka memiliki pengalaman, wawasan, dan pengetahuan yang luas. Selain itu, ide cerita atau tema pada cerpen dapat diambil dari pengalaman-pengalaman hidup.

Menurut Vygotsky (1992: 57), interaksi sosial dapat memberikan berbagai pengalaman, wawasan, dan pengetahuan, ini terjadi karena adanya perubahan dari proses interpersonal menuju proses intrapersonal dan proses tersebut dimulai dari memperhatikan peristiwa yang terjadi kemudian disimpan dalam ingatan yang akhirnya menghasilkan pengalaman dan pengetahuan. Dengan demikian, siswa yang sering berinteraksi sosial, maka akan memiliki pengalaman yang beragam, pengetahuan yang banyak, dan wawasan yang luas. Telah dibicarakan di awal bahwa ide, tema, atau topik akan mudah didapatkan siswa apabila mereka memiliki pengalaman, wawasan, dan pengetahuan yang luas. Untuk itu, siswa yang sering berinteraksi sosial kemungkinan akan mudah mendapatkan ide, tema, atau topik untuk tulisan cerpennya.

Di sini peneliti menduga adanya hubungan dari kemampuan berinteraksi sosial dengan kemampuan menulis cerpen. Peneliti berasumsi jika semakin tinggi kemampuan berinteraksi sosial siswa, maka semakin tinggi pula kemampuan menulis cerpennya. Hal ini dikarenakan kemampuan berinteraksi sosial dapat memudahkan siswa dalam mendapatkan ide, tema, atau topik untuk tulisan cerpennya.

Selain itu, dari pengalaman peneliti saat mengajar di MAN 13 Jakarta, peneliti juga menemukan bahwa siswa yang sering berinteraksi sosial memperoleh nilai lebih tinggi pada hasil tulisan cerpennya, daripada siswa yang pendiam dan jarang berinteraksi. Hal ini membuat peneliti semakin tertarik untuk melakukan penelitian terkait hubungan kemampuan berinteraksi sosial dengan kemampuan menulis cerpen. Peneliti akan mencari tahu apakah memang ada hubungan kemampuan berinteraksi sosial dengan kemampuan menulis cerpen pada siswa.

\section{Metode}

Berdasarkan data yang digunakan, ada tiga jenis penelitian, yaitu penelitian kualitatif, kuantitatif, dan gabungan kualitatif dan kuantitatif. (Wijayanti, 2013:222). Dari pembagian tiga jenis tersebut, dapat diringkaskan bahwa jenis penelitian dapat dibedakan atas dua macam, yaitu penelitian kualitatif dan penelitian kuantitatif. Penelitian kualitatif mendapatkan data berupa deskripsi pendapat dari responden ataupun hasil catatan lapangan, sedangkan metode kuantitatif mendapatkan data yang berupa angka, skala, maupun grafik yang bisa dihitung. Adapun jenis penelitian makalah ini adalah penelitian kualitatif.

Metode penelitian yang digunakan dalam penelitian ini adalah metode deskriptif. Dalam penelitian dengan metode deskriptif ini akan dideskripsikan suatu fenomena dengan berdasarkan pada pengalaman dan hasil observasi kepustakaan yang telah dilakukan. Jadi, metode yang digunakan dalam penelitian ini adalah kualitatif deskriptif.

Tahapan observasi kepustakaan pada penelitian ini, pertama peneliti melakukan observasi langsung pada siswa MAN 13 Jakarta. Selanjutnya, peneliti melakukan wawancara kepada beberapa siswa MAN 13 Jakarta. Setelah itu, peneliti mengkaji dan menganalisis teori kemampuan berinteraksi sosial dan teori kemampuan menulis cerpen, mencari tahu bagaimana hubungan kemampuan berinterakasi sosial dengan kemampuan menulis cerpen.

\section{Hasil dan Diskusi}

Menulis adalah kegiatan merangkai kata dan kalimat sedemikian rupa, untuk mengungkapkan dan menyampaikan informasi serta gagasan kepada pembaca agar dapat dipahami. Salah satu jenis kegiatan menulis adalah menulis kreatif. Menulis cerpen merupakan bagian atau kegiatan dari menulis kreatif. Yunus (2015: 7) mengatakan, "menulis kreatif dapat didefinisikan sebagai proses menulis yang bertumpu pada pengembangan daya cipta dan ekspresi pribadi dalam bentuk tulisan yang baik dan menarik." Pengertian ini mengartikan bahwa menulis kreatif menekankan pada proses aktif seseorang untuk 
menuangkan ide dan gagasan melalui cara yang tidak biasa sehingga mampu menghasilkan karya yang berbeda, baik, dan juga menarik, seperti cerpen.

Menurut Naning Pranoto (2004: 6), proses menulis yang bersifat kreatif disebut penulisan kreatif (creative writing). Bersifat kreatif karena penulis harus mereka-reka sedemikan rupa dengan memasukkan imajinasi, pengalaman nyata, serta memasukkan unsur seni, khususnya seni sastra. Naning juga menyatakan bahwa creative writing bisa disebut sebagai pelajaran mengarang yang berarti menciptakan sebuah dunia rekaan, dunia imajiner, atau dunia yang berbeda dibandingkan dengan dunia nyata yang kita hadapi. Untuk itu, creative writing berkaitan dengan dunia yang tidak nyata, yakni fiksi (fiction).Namun, karya fiksi tidak seluruhnya berisi imajinasi atau khayalan belaka. Penulis karya fiksi dapat memasukan pengalaman nyata yang berupa pengalaman yang pernah terjadi pada dirinya sendiri maupun orang-orang sekitarnya. Melalui proses kreatif penulis, pengalaman yang nyata dapat dijadikan fiksi atau difiksikan. Adapun salah satu karya creative-writing adalah cerpen.

Cerpen atau cerita pendek adalah karya sastra fiksi yang pendek. Kosasih (2012: 60-71) berpendapat bahwa cerpen adalah karangan pendek berbentuk prosa yang dibentuk oleh beberapa komponen, yakni tema, alur, latar, penokohan, sudut pandang, amanat, dan gaya bahasa. Dapat disimpulkan bahwa menulis cerpen merupakan kegiatan menuangkan ide atau gagasan, pengalaman, perasaan, serta imajinasi ke dalam bentuk prosa fiksi yang pendek yang di dalamnya memuat unsur-unsur struktur cerpen berupa tema, alur, latar, penokohan, sudut pandang, amanat, dan gaya bahasa.

Syarbaini, Rudiyanta, dan Fatkhuri (2012: 57-58) berpendapat bahwa interaksi sosial adalah hubungan-hubungan sosial yang dinamis yang menyangkut hubungan timbal-balik antara individu dengan individu, antara individu dengan kelompok (guru dengan siswa), atau kelompok dengan kelompok lain (siswa kelas XI IPA dengan siswa kelas XI IPS). Hubungan yang dinamis berarti hubungan yang dilakukan antar dua belah pihak akan selalu mengalami dinamika sesuai dengan kebutuhan, tidak statis dan tidak monoton.

Interaksi sosial pada dasarnya merupakan hubungan-hubungan sosial timbal-balik yang dinamis antara individu dengan individu, individu dengan kelompok, atau kelompok dengan kelompok dalam rangka mencapai tujuan tertentu yang terjalin terus-menerus dalam kehidupan sehari-hari, di mana dari proses tersebut akhirnya menghasilkan berbagai pengalaman dan pengetahuan. Pengalaman dan pengetahuan ini merupakan modal untuk ide dan tema dalam menulis cerpen. Sebagaimana yang telah diutarakan oleh Stanton (2012: 36), tema merupakan aspek cerita yang sejajar dengan makna dalam pengalaman manusia, seperti sesuatu yang menjadikan suatu pengalaman begitu diingat. Maksud ungkapan Staton ini mengartikan bahwa sama halnya dengan makna pengalaman manusia, tema menyorot dan mengacu pada aspek-aspek kehidupan. Untuk itu, hampir semua gagasan yang ada dalam kehidupan ini bisa dijadikan tema, ide, dan topik untuk cerpen. Tema diambil dari pengalamanpengalaman hidup, baik pengalaman pribadi, maupun pengalaman orang-orang di sekitar yang didapat dari interaksi sosial.Karena cerpen merupakan karya fiksi atau karya rekaan, maka pengalamanpengalaman tersebut dibumbui imajinasi penulis sehingga cerita menjadi lebih menarik, memukau, dan dramatis.

Purwanto (2007: 35-36) turut berpendapat bahwa manusia dalam melakukan interaksi sosial menggunakan berbagai daya yang disebut daya-daya jiwa, daya jiwa tersebut salah satunya adalah pengamatan, pengamatan merupakan daya jiwa untuk memasukan kesan-kesan yang didapat dari luar melalui pancaindra dan akhirnya menghasilkan kesan-kesan yang berupa tanggapan atau pengertian, kesan-kesan inilah yang kemudian menjadi pengalaman-pengalaman serta pengetahuan yang dimiliki seseorang. Dengan demikian, siswa yang sering berinteraksi sosial, maka akan memiliki pengalaman yang beragam, pengetahuan yang banyak, dan wawasan yang luas. Telah dibicarakan di awal bahwa ide, tema, atau topik akan mudah didapatkan siswa apabila mereka memiliki pengalaman, wawasan, dan pengetahuan yang luas. Untuk itu, siswa yang sering berinteraksi sosial akan mudah mendapatkan ide, tema, atau topik untuk tulisan cerpennya.

Naning Pranoto (2015: 15) mengutip pernyataan dari seorang cerpenis Indonesia bernama Hamsad Rangkuti yang menyatakan bahwa makin banyak bergaul dan memahami dunia serta karakter 
orang, maka makin banyak ide yang didapatkan. Hal ini mengartikan bahwa orang yang makin banyak bergaul atau berinteraksi sosial dengan memahami peristiwa serta karakter orang-orang, maka akan makin banyak ide yang ia punya.

Orang yang sering berinteraksi sosial dengan baik, ia akan memiliki pengalaman yang beragam, pengetahuan yang banyak, dan wawasan yang luas, sehingga interaksi sosial akan memudahkan siswa dalam mendapatkan ide, menentukan tema, dan mengeluarkan gagasan. Oleh karena itu, ini memperlihatkan adanya hubungan interaksi sosial dengan kemampuan menulis cerpen.

\section{Simpulan}

Berdasarkan kerangka teoretik dan temuan penelitian, maka kesimpulan dalam penelitian ini adalah terdapat hubungan antara kemampuan berinteraksi sosial dengan kemampuan menulis cerpen. Upaya meningkatkan kemampuan menulis cerpen melalui peningkatan interaksi sosial yaitu dengan menginformasikan pada siswa bahwa manusia sebagai makhluk sosial tidak dapat hidup sendiri, mereka perlu berinteraksi sosial, kemudian membimbing siswa untuk dapat saling bekerjasama, membuat kelompok-kelompok belajar kecil di kalangan siswa, mendorong siswa untuk aktif di dalam kegiatan ekstrakurikuler sekolah, membimbing dan mengarahkan siswa dalam bergaul, serta mengarahkannya agar dapat mengambil sisi positif dari kegiatan interaksi sosial, salah satunya dengan mengambil pengalaman orang lain untuk menjadi bahan atau tema cerpen.

\section{Ucapan Terima Kasih}

Dengan selesainya penelitian ini, peneliti panjatkan puji dan syukur ke hadirat Allah SWT. Tak lupa juga, peneliti ucapan terima kasih yang tak terhingga kepada tim redaksi Hortatori atas bantuannya dalam menerbitkan hasil penelitian ini, para siswa yang bersedia dijadikan objek penelitian, teman-teman sejawat atas kesediaan membantu peneliti, dan keluarga yang dengan sabar dan pengertian turut memberi dukungan moral kepada peneliti dalam menyelesaikan penelitian ini. Akhir kata, semoga penelitian ini dapat memberi manfaat dan sumbangsih bagi ilmu pengetahuan,

\section{Daftar Rujukan}

Kosasih, E. Dasar-dasar Keterampilan Bersastra. Bandung: Yrama Widya, 2012.

Pranoto, Naning. Creative Writing. Jakarta: PT Primamedia Pustaka, 2004.

Pranoto, Naning. Seni Menulis Cerita Pendek. Jakarta: Opuss Agrapana Mandiri, 2015.

Purwanto, Ngalim. Psikologi Pendidikan. Bandung: PT Remaja Rosdakarya, 2007.

Ridwan, Sakura. Metodologi Pembelajaran Bahasa: Aplikasi dalam Pengajaran Morfologi-Sintaksis. Yogyakarta: Kepel Press, 2011.

Stanton, Robert. Teori Fiksi Robert Stanton terjemahan Sugihastuti dan Rossi Abi Al Irsyad. Yogyakarta: Pustaka Pelajar, 2012.

Syarbaini, Syahrizal, Rusdiyanta, dan Fatkhuri. Konsep Dasar Sosiologi dan Antropologi: Teori dan Aplikasi. Jakarta: Hartono Media Pustaka, 2012.

Vygotsky, L. S. Mind in Society: The Development of Higher Psychological Processes. Cambridge: Harvard University Press, 1992.

Wijayanti, Sri Hapsari, dkk. Bahasa Indonesia: Penulisan dan Penyajian Karya Ilmiah. Jakarta: Divisi Buku Perguruan tinggi PT RajaGrafindo Persada, 2013.

Yunus, Syarifudin. Kompetensi Menulis Kreatif. Bogor: Ghalia Indonesia, 2015. 